\title{
Impediments to Quality Research in Business Education in Nigeria Tertiary Institutions
}

\author{
Titus A. Umoru ${ }^{1, *}$ \\ ${ }^{1}$ Department of Business Education, Kwara State University, Malete, Nigeria \\ *Correspondence: Kwara State University, Malete, Nigeria. E-mail: umoruglo@yahoo.com
}

Received: October 12, 2013 Accepted: November 19, $2013 \quad$ Online Published: December 17, 2013

doi:10.5430/wje.v3n6p81～URL: http://dx.doi.org/10.5430/wje.v3n6p81

\begin{abstract}
Research is a systematic investigation towards increasing the sum of human knowledge. Research in business education is aimed at increasing knowledge in the discipline and providing solutions to problems relating to curriculum, program evaluation and overall improvement in the teaching and learning process. There is no doubt that very high quality research in business education would lead to improvement in educational practice which Nigeria needs direly in order to break into the bracket of the twenty most developed economies in the year 2020. This study explored the impediments to the quality of business education research in Nigeria tertiary institutions. The researcher constructed 32 questionnaire items from research reports relevant to the study. The questionnaires were validated using Product Moment Coefficient which yielded a reliability coefficient of 0.81 . A total of 159 questionnaire items were administered on 96, 38 and 25 business educators from Colleges of Education, Polytechnics and universities in Nigeria respectively and all the questionnaires were completed and retrieved. The Research Question "what are the impediments to the quality of business education research in Nigeria tertiary institutions?” was answered using mean rating and standard deviation. The Hypothesis of no significant difference in the mean responses of business educators from Colleges of Education, Polytechnics and Universities regarding the impediments to the quality of business education research was tested using Analysis of Variance. The study revealed that all the constructs studied constituted impediments to the quality of business education research in Nigeria tertiary institutions. It was recommended, among others, that researchers in the field of business education should ensure that only quality information is used in the research process so that research results would significantly influence changes in the directions desired.
\end{abstract}

Keywords: impediments; quality research; business education

\section{Introduction}

Research is a systematic investigation towards increasing the sum of human knowledge. The most important tool often used to understand a problem, delineate issues relating to it and resolving conflicts surrounding it, is research (Umoru, 2010). Osuala (2005) defined research as a process of arriving at dependable solutions to problems through the planned and systematic collection, analysis and interpretation of data. He further explained that research is the most important tool for advancing knowledge, for promoting progress, and for enabling man to relate more effectively to his environment, to accomplish his purposes, and to resolve his conflicts. Arising from this definitions therefore, research in business education is aimed at increasing knowledge in the discipline and providing solutions to problems relating to curriculum, evaluation, students and teachers, the society, all aimed at improving the quality of teaching and learning process. According to Okeke (2004) there is a serious need for professionals to embark on research as a way of finding solutions to numerous problems affecting the education sector. This view was supported by Njoku (2003) who argued that results of research should help business educators solve educational problems. However, it does appear that researchers in the field of business education embark on research only for the sake of it. Otherwise, how can it be explained that the education sector is confronted with many problems threatening to defy solution to the extent that the Federal Government of Nigeria Plans to declare a state of emergency in the education sector?

There is no doubt that researchers in the industry are trained in the art of research investigation so as to understand 
the general physical relationship of cause and effect and the ability to test specific relations experimentally and systematically. This is important because according to Preece (1998) only systematically trained mind is likely to be aware of the possible significance of any chance observation from which develops an intuitive idea or a hunch. This mental process, he further explained, is called induction and he argues that these inductively formed ideas must be tested systematically according to procedures which are in part general to all disciplines but are also, to some extent, specific to individual subjects.

The strict adherence to the scientific procedure in research investigation is unavoidable if the quality of research in business education must be of high standard. High quality research is useful as it influences development in the field of education since education is central to creating and sustaining any modern society. A useful research, in purely academic terms, according to Preece (1998) means that which is carried out within the system of knowledge of a particular subject or discipline and contributes to or modifies or even casts doubt on - in fact tests - that system.

The use of qualitative and quantitative research in business education is necessary and complimentary in improving the quality of research results. Qualitative method is useful in providing material for hypothesis, and defining complex concepts rigorously and realistically. On the other hand, quantitative research in business education is valuable for hypothesis testing, logical argument, generalization and objectivity. If the researcher is competent in all aspects of research handling, then it is expected that high quality research would result which, in turn, will transform the society and bring about improved standard in the education sector generally and in business education discipline in particular.

\subsection{Statement of the Problem}

The need to improve the quality of business education research in Nigeria tertiary institutions is pressing indeed. The Federal Government is working hard to fast-track socio-economic development of Nigeria. Hence it has enunciated the Nigeria Vision 2020 which is a perspective plan; an economic business plan intended to make Nigeria one of the 20 fully developed economies by the year 2020. Again, the World Bank (2008) named Nigeria as one of the "next eleven" emerging economies using macroeconomic stability, political maturity, openness to trade and investment policies and quality of education as criteria, thus increasing pressure on the government to deliver. It is recognized that higher levels of education are generally helpful in contributing to more rapid growth and catch-up in every area of human endeavor. The use of research as an instrument of change in the higher levels of business education research is congruent in this effort. However, numerous factors have constituted obstacles in the realization of this goal. Therefore, any effort geared towards removing or reducing these impediments would be significant. The obvious benefits would include quality teaching and learning that will engender break-through in prototype and product manufacturing and service delivery in the discipline.

Researchers should realize that transfer of information from one place to another, does not in itself constitute serious research. It is an inferior type, since it can pass as an incremental knowledge. Objectivity which is essential in research, is external to the mind, real, existing in nature which is in contrast with what is ideal or exists in the mind of the researcher. Furthermore, the issue of measurement is an area of great difficulty which according to Summers (1977) elude scientists who do not understand that while there are well established and accepted general procedures which purport to measure attitudes, these should only be used with some understanding of the problems of attitude measurement. Very clearly then, the quality of information in research is very important for a good research without which argument, conclusions, and results will largely be valueless. The observation of Donwa (2006) is instructive that Nigeria is not acclaimed for world class research because the universities which should be centers of research and knowledge creation are handicapped and have not been able to tap into potential areas of research. Similarly, the Nigerian education system has often been the butt of severe criticisms and the perception is wide spread that the system lacks the virility to stimulate needed growth for attainment of educational objectives. Therefore, the problem of this study is to reveal the impediments to quality research in business education in Nigeria tertiary institutions.

\subsection{Research Question}

What are the impediments to quality research in business education in Nigeria tertiary institutions?

\subsection{Hypothesis}

There is no significant difference in the mean responses of business educators of Colleges of Education, Polytechnics and Universities on the impediments to quality research in business education in Nigeria tertiary institutions. 


\section{Methods}

\subsection{Population of the Study}

This study was a descriptive survey design. The Population of the study consisted 192 business educators from Colleges of Education, 77 from Polytechnics and 51 from Universities. The population was obtained from the membership directory of the Association of Business Educators of Nigeria. This is the official population frame of all business educators in Nigeria tertiary institutions.

\subsection{Sampling Technique}

Stratified random sampling technique was adopted in selecting $50 \%$ each of the business educators from Colleges of Education, Polytechnics and Universities in Nigeria which yielded 96, 38 and 25 respondents respectively.

\subsection{Instrument}

The questionnaire was the data gathering instrument used. It was constructed after careful review of literature relating to the study, especially Umoru (2010) and Eze (2010). A reliability coefficient of 0.81 was obtained using Cronbach Alpha statistics implying that the questionnaire items have internal consistency. All items in the questionnaire were stated in a modified Likert format ranging from 1 -Strongly Disagree; 2 - Disagree; 3 - Agree; and 4 - Strongly Agree. The questionnaire contained a total of 32 items. A total of 159 copies of the questionnaire were administered to the respondents during the National Conference of the Association of Business Educators of Nigeria held at the Federal Polytechnic, Nekede, from $12^{\text {th }}$ to $15^{\text {th }}$ October, 2012. All the questionnaires were duly completed and retrieved by the researcher with the help of ten colleagues.

\subsection{Techniques for Data Analysis}

The Research Question was answered using the mean which was computed by multiplying the frequency count of each response option with the corresponding value of the response category and dividing it by the number of responses to each question. A criterion mean that was equal to or greater than 2.50 was taken as agreed, while a mean that was equal to or less than 2.49 was taken as disagreed. The hypothesis was tested using ANOVA statistics at 0.05 level of significance. If the calculated $F$-ratio value was equal or greater than the given critical $F$-ratio value, the null hypothesis was rejected. If the obtained value of $F$-ratio was less than the given critical $F$-value, the null hypothesis was accepted.

\section{Results}

\subsection{Research Question}

What are the impediments to the quality of research in business education in Nigeria tertiary institutions?

Table 1: Mean Responses of the Opinion of Business Educators on the Impediments to Quality Research in Business Education in Nigeria Tertiary Institutions

\begin{tabular}{lllll}
\hline S/No. & Item Statement & Mean & $\boldsymbol{\sigma}$ & Decision \\
\hline 1. & Difficulty in obtaining current literature. & 3.69 & 0.69 & Agree \\
2. & Poor knowledge of research results. & 3.50 & 0.73 & Agree \\
3. & Poor research selection techniques. & 3.66 & 0.48 & Agree \\
4.. & Recycling of old research topics. & 3.23 & 0.45 & Agree \\
5. & Poor knowledge of citation. & 3.07 & 0.26 & Agree \\
6. & Poor knowledge of referencing. & 3.68 & 0.73 & Agree \\
7. & Poor selection of statistical tools. & 3.01 & 0.37 & Agree \\
8. & Poor use of statistical tools. & 2.98 & 0.39 & Agree \\
9. & Failure of research to contribute to knowledge. & 2.92 & 0.54 & Agree \\
10. & Lack of access to new technologies. & 3.98 & 0.12 & Agree \\
11. & Inadequate skills to use new technologies. & 3.72 & 0.68 & Agree \\
12. & Poor conceptualization of research problem. & 3.75 & 0.65 & Agree \\
13. & Poor clarification of relationships between variables. & 3.02 & 0.42 & Agree \\
\hline
\end{tabular}




\begin{tabular}{lllll}
\hline 14. & Wrong presumptions about validity and reliability of instruments. & 3.05 & 0.28 & Agree \\
15. & Poor knowledge of differences between common sense and scientific & 3.45 & 0.87 & Agree \\
& research. & & & \\
16. & Poor quality of information used. & 3.82 & 0.39 & Agree \\
17. & Lack of objectivity. & 2.92 & 0.36 & Agree \\
18. & Poor generalization of findings. & 3.18 & 0.93 & Agree \\
19. & Poor procedure in attitude measurement. & 3.20 & 0.93 & Agree \\
20. & Skewed preference of quantitative over qualitative methods. & 3.41 & 076 & Agree \\
21. & Non-availability of congruent and sufficient information. & 2.96 & 0.29 & Agree \\
22. & Poor construction of questionnaire items. & 3.31 & 1.01 & Agree \\
23. & Difficulty in verification and replication of research reports. & 3.19 & 1.18 & Agree \\
24. & Absence of true experimental studies. & 2.85 & 0.50 & Agree \\
25. & Recommendations not emanating from the findings. & 3.58 & 0.93 & Agree \\
26. & Discrepancy between data collected and tools used in analysis. & 3.90 & 0.39 & Agree \\
27. & Poor grasp of critical methods of data analysis. & 3.97 & 0.17 & Agree \\
28. & Poor interpretation of results. & 3.54 & 0.69 & Agree \\
29. & Poor coding of raw data. & 3.74 & 0.54 & Agree \\
30. & Lack of access to quality journals. & 3.97 & 0.17 & Agree \\
31. & Poor sampling procedure. & 3.29 & 0.94 & Agree \\
32. & Poor funding of business education research. & 3.72 & 0.63 & Agree \\
\hline
\end{tabular}

The data presented in Table I revealed that all the items have mean values ranging from 2.92 to 3.98. This showed that all the means were well above the cut-off point of 2.50 indicating that the respondents agreed that the items have the potential to undermine the quality of business education research in Nigeria tertiary institutions. It should be noted with interest that the means are extremely very high indicating the danger inherent in the research process as now obtained in the discipline. The standard deviation scores of 0.12 to 1.18 showed low variability of the respondents' views on all the items indicating that there were little or no disagreements in their opinions.

\subsection{Hypothesis}

There is no significant difference in the mean responses of business educators of Colleges of Education, Polytechnics and Universities on the impediments to quality business education research in Nigeria tertiary institutions.

Table 2: Summary of the Analysis of Variance on the Mean Response of Business Educators on the Impediments to Quality Research in Business Education in Nigeria Tertiary Institutions

\begin{tabular}{|c|c|c|c|c|c|c|c|}
\hline $\begin{array}{l}\text { Sources of } \\
\text { Variation }\end{array}$ & $\begin{array}{l}\text { Sum of } \\
\text { squares }\end{array}$ & $\begin{array}{l}\text { Degree of } \\
\text { Freedom }\end{array}$ & $\begin{array}{l}\text { Mean } \\
\text { Squares }\end{array}$ & F-cal. & F-Tab. & $\begin{array}{l}\text { Level of } \\
\text { Significance }\end{array}$ & Decision \\
\hline Between & 18.18 & 2 & 9.95 & & & & \\
\hline Groups & & & & 1.790 & 3.15 & 0.05 & Accept \\
\hline $\begin{array}{l}\text { Within } \\
\text { Groups }\end{array}$ & 199418.44 & 93 & 2144.28 & & & & \\
\hline
\end{tabular}

The result of Table 2 showed that the calculated $F$-value of 1.790 was less than the critical $F$-value of 3.15 with 2 and 93 degrees of freedom at 0.05 level of significance. The hypothesis of no significant difference was accepted. This meant that the business educators agreed on the items as constituting impediments to quality research in business education in Nigeria tertiary institutions.

\section{Discussion of Findings}

The study was carried out to ascertain factors undermining the quality of business education research in Nigeria tertiary institutions. All the constructs examined have been confirmed to undermine the quality of the research 
process. On the items relating to the process of research selection, sampling, objectivity and poor construction of questionnaire, the study found that they are the reasons research results in business education are heavily criticized. This view was supported by Nwagu in Ezeh (2005), Nworgu (2006), and Ali (2006) who found that in business education research there has been wide spread abuse of research process which they claimed was due to lack of required skill and competence on the part of the researcher. On items affecting sampling and poor generalization of findings, the study found that this was due to poor handling and according to Obora (2010) this affects the generalization of research results in business education. Also, wrong presumptions about validity and reliability of instrument, the study found, undermine the quality of research in business education which Obora insisted may yield results that are not dependable. The study also found that researches are recycled and this was supported by Jimoh-Kadiri (2011) who reported that as a result of "publish or perish syndrome, some lecturers copy other researchers' work without even acknowledging them” (p. 34). Regarding the absence of newtechnologies, the study found that this affects the outcome of research endeavor negatively as effective research is impossible without the use of new technologies. In this regard, (Bingimlas (2009) reported that the use of new technologies is no doubt essential as it provides opportunities for students to learn to operate in an information age. Moreover, Long and Long (1999) reported that the academic society was heavily adopting new approach to seeking information through information and communication technologies as a solution in their research endeavors. The study confirmed some items such as lack of access to quality journals and libraries; poor quality of information gathered and poor interpretation of results as impediments to the quality of research in business education. These were heavily supported by previous studies, especially the study of Nwanewezi (2010), which affirmed that new research environment requires learning of new skills, competencies and attitudes as a way of removing the identified impediments to quality research in business education.

Furthermore, Rai and Bhattacharya (2011) found that the quality of an institution's environment for digital information storage and retrieval has, for business education research, become more important than the conventional library and need to be available and used adequately. Poor funding of business education research was found to be major obstacle towards quality research in the discipline in Nigeria. Okebukola (2008) reported that the depressed quality of education in Nigeria has been explained in part by the inadequate funding of the system. All stakeholders in education including parents, students, teachers, development partners, he continued, have listed funding inadequacy as a problem; all communiqués and resolutions of major conferences and summits on the state of education in Nigeria have funding as an issue that should be addressed in order to get education on good track. According to him, funding is far from the pace required for a quantum leap in improving quality.

\section{Conclusion}

The study reviewed the factors undermining the quality of business education research in Nigeria tertiary institutions. It was very clearly revealed that there was a serious need for educational professionals to continue to embark on research as a way of finding solutions to numerous problems facing the society generally and the education sector in particular. Quality research results are crucial if the required educational goals must be achieved by any country and this is only possible when the impediments identified by this study are eliminated.

\section{Recommendations}

Based on the findings of this study, the following recommendations were made:

1. Researchers in the field of business education should ensure that only quality information is used in the research process so that research results would significantly influence changes in the directions desired.

2. New technologies should be provided by tertiary institutions so that researchers in the field of business education would have access to research materials.

3. The libraries in tertiary institutions should be well equipped with current books and journals so that researchers would have opportunities for healthy consultation.

4. The federal government should fund tertiary institutions so that researchers would have the capacity to play their research role effectively. 
5. Business education researchers should be provided with capacity building needed for effectiveness in the research process and competence in handling new technologies which are useful in research investigation.

\section{References}

Ali, A. (2006). Conducting Research in Education and Social Sciences. Enugu: Tashiwa Networks Ltd.

Bingimlas, K. A. (2009). Barriers to the Successful Integration of ICT in Teaching and Learning Environments: A Review of the Literature, Eurasia Journal of Mathematics, Science \& Technology Education, 5(3), 235-245.

Donwa, P. A. (2006). Funding of Academic Research in Nigerian Universities. A Paper Presented at the Second International Colloquium of Research and Higher Education Policy. UNESCO Headquarters, Paris.

Ezeh, C. E. (2010). Problems Militating Against Research in Business Education in Selected Tertiary Institutions in Nigeria. Business Education Journal, 7(2), 55-59.

Jimoh-Kadiri, S. O. (2010). Problems of Business Education Research in Tertiary Institutions. Business Education Journal, 6(2), 31-37.

Long, L., \& Long, N. (1999). Computers. (6 $6^{\text {th }}$ Ed.). New Jersey: Prentice Hall.

Njoku, C. U. (2003). Policy and Strategic Framework for Utilizing Business Education Research. Business Education Journal, 6(2), 77-94.

Nwachukwu, K. O. (2003). A critical Analysis of the State of Research Undertaking in Nigeria's Higher Institutions. International Journal of Economic and Development Issues, 3(1), 198-208.

Nwagu, E. K. N. (2005). Method of Research. In D. N. Ezeh. What to Write and How to Write: A step by Step Guide to Educational Research Proposal and Report. Nsukka: Trust Publishers.

Nwanewezi, M. C. (2010). Attitude of Polytechnic Academic Staff toward the Utilization of Internet Services for Educational Research. Journal of Information Search, 2(1), 49-57.

Nworgu, B. G. (2006). Educational Research: Basic Issues and Methodology, ( ${ }^{\text {nd }}$ Ed.). Nsukka: University Trust Publishers.

Oborah, J. O. (2010). Research Designs, Sampling Techniques and Instruments Commonly Employed in Business Education Research. Business Education Journal, 7(2), 1-10.

Okebukola, P. (2008). Education Reform Imperatives for Achieving Vision 20-2020. Presented at the National Summit on Education, December 10-11.

Okeke, B. S. (2004). Qualitative Research in Education: Supervisor's Perspective. Port Harcourt: Pam Unique Publishing.

Osuala, E. C. (2005). Research Methodology. Enugu: New Generation Books.

Preece, R. (1998). Starting Research: An Introduction to Academic Research and Dissertation Writing. London: A Cassel Imprints.

Rai, K., \& Bhattacharya, P. K. (2011). Implications of Information Technology for Teacher Education and Research. Retrieved June, 2011 from http://www.ciet.nic.in/welcome.html

Summers, G. F. (1977). Attitude Measurement. London: Kershaw.

Umoru, T. A. (2010). Analysis of Factors undermining the Utilization of Research Results in Business Education. Business Education, Journal, 7(2), 70-76.

World Bank (2008). Accelerating Catch-up: Tertiary Education for Growth in Sub-Saharan Africa. The World Bank, Washington DC. 